\section{Oceans of garbage}

SIR - Ducie Atoll in the south Pacific $\left(24^{\circ} 40^{\prime}\right.$ $\mathrm{S}, 124^{\circ} 47^{\prime} \mathrm{W}$ ) is one of the most remote islands in the world. It is 293 miles away from the nearest inhabited island (Pitcairn Island, population around 50), and more than 3,000 miles away from the nearest continent.

As part of the Sir Peter Scott commemorative expedition to the Pitcairn Islands I visited Ducie at the end of the March and surveyed the seaward shore of Acadia, the largest island in the atoll, for pieces of non-biodegradable flotsam of human origin. The survey was a belt transect, 1.5 miles long: I walked along the shore and recorded the objects I saw. The list is not complete: obviously the method is biased against smaller objects which were less visible from a distance. In total I recorded 953 objects, listed in the table.

Ducie is rarely visited: it has little to offer to passing boats (of which there are probably about 30 yachts per year en route between Easter Island and French Polynesia). There is no standing fresh water on the island, and the one species of plant found there is not edible. Pieces of pumice and tree-fern trunks attest to the ability of objects to float from South America, but most flotsam is likely to come from ships throwing their rubbish overboard.

On nearby Henderson Island (190 miles west of Ducie) I found equally bizarre flotsam on the beaches. In more than 3 months beachcombing, I found enough toy soldiers

\section{HARVEST FROM DUCIE ATOLL}

\section{Buoys: large (usually $30 \mathrm{~cm}$ diameter)} small (usually $20 \mathrm{~cm}$ diameter) pieces (glass, plastic, polystyrene)

Crates (bread, bottle)

Plastic bottles (drinks, toiletries)

Glass bottles (produce of $>15$ countries,

$35 \%$ once contained whisky) Jars

Unidentified (or broken) plastic pieces

Bottle tops

Segments of plastic pipe

Pieces of rope

Shoes

Fluorescent tubes

Light bulbs

Aerosol cans

Food/drink cans

Biro tops

Jerry cans (all holed)

Gloves ( 1 pair)

Tinned meat pie (leaking, but intact)

Cigarette lighters (non functional)

Doll's heads ( 1 male, 1 female)

Copper sheeting from hulls of wrecks

Lorry tyre

Plastic skittle

Glue syringe

Small gas cylinder

Construction-worker's hat (brown)

Plastic coat hanger

Toy soldier

Toy aeroplane

Tea strainer

Football (punctured)

Plastic foot mat from car

Asthma inhaler (six) and vehicles (two jeeps and a tank) to make a toy army, as well as such diverse items as full bottles of body lotion and a medical syringe with an attached needle.

If so much rubbish is washed ashore on these small and extremely isolated islands, it makes one wonder just how much more is still floating on the surface of the oceans.

Department of Zoology,

TIM BENTON

University of Cambridge,

Downing Street,

Cambridge CB2 3EJ, UK

\section{$\mathrm{Ca}^{2+}$ channels or voltage sensors?}

SIR - There is considerable confusion about the precise role and possible diversity of dihydropyridine receptors (DHPRs) in skeletal muscle: at least some of these receptors must act as voltage-dependent calcium channels in the surface membrane ${ }^{1,2}$ whereas others act as voltage-sensors controlling the calcium release channel/foot structures in sarcoplasmic reticulum ${ }^{3,4}$. It has been suggested that only a small fraction of DHPRs are 'functional' calcium channels ${ }^{1}$, but this may be true only at a given instant and all these receptors may perhaps act as calcium channels at some time ${ }^{2}$. Thus the possibilities are that: (1) there are two fundamentally different types of DHPR, a few being calcium channels and almost all being voltagesensors which are inherently unable to act as calcium channels ${ }^{5} ;(2)$ all DHPRs can be calcium channels, with some local factor in vivo dictating that each is either a voltagesensor or a calcium channel, either permanently or at a particular instant; or (3) a DHPR can simultaneously have both functions ${ }^{2}$.

In support of (1), Catterall and colleagues have suggested ${ }^{5}$ that only few $(2-3 \%)$ of the DHPRs have the complete $M_{\mathrm{r}} 212,000$ $(212 \mathrm{~K})$ sequence and can act as calcium channels, whereas most have had part of their C-terminal end removed, reducing them to $175 \mathrm{~K}$ proteins which can act only as voltage-sensors and not as calcium channels. (This would mean that all previous biochemical studies were incorrect in attributing calcium channel activity to the $175 \mathrm{~K}$ form, and also does not explain a similar difference between the measured and predicted size of the receptor in cardiac muscle.) However, Catterall's group also found ${ }^{6}$ that phosphorylation of the DHPRs increased the number of 'functional' calcium channels incorporated into lipid vesicles at least nine times, implying that many if not all of the receptors function as calcium channels (at least $36-54 \%$, assuming that only half of the receptors were 'inside-out' and could be phosphorylated), thus eliminating hypothesis (1).
A further insight comes from experiments involving the expression of cardiac and skeletal muscle DHPRs in dysgenic skeletal muscle ${ }^{7,8}$, in which a similar ratio of calcium channel conductance to charge movement is found for both types of receptor ( 36 and 85 $\mathrm{nS} \mathrm{pC}^{-1}$ for expressed and native skeletal DHPRs and $55 \mathrm{nS} \mathrm{pC}^{-1}$ for expressed cardiac DHPRs). Assuming that the non-linear charge movement indicates the number of receptors present, Adams et al. suggest that "the two types of DHPR do not appreciably differ in their ability to function as chan-

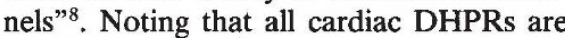
usually thought to be calcium channels, this seems to support hypothesis (3). However, consideration of the absolute ratios shows that the situation is more complicated than it first appears: the above ratios are virtually the same as that found previously in adult skeletal muscle ${ }^{2}$ (about $50 \mathrm{nS}$ $\mathrm{pC}^{-1}$ in three different muscle types, using the nifedipine-sensitive charge movement and allowing for $10 \mathrm{mM} \mathrm{Ca}^{2+}$ ), but are four to eight times lower than that for calcium channels in cardiac cells ${ }^{9}\left(>300 \mathrm{nS} \mathrm{pC}^{-1}\right.$ for $10 \mathrm{mM}$ free $\mathrm{Ca}^{2+}$ ). Noting also that the number of skeletal muscle DHPRs expressed in non-skeletal muscle cells agrees well with the apparent number of functional calcium channels ${ }^{10}$, it appears that when either cardiac or skeletal muscle DHPRs are expressed in a skeletal muscle cell, the current per receptor is much lower than either when cardiac receptors are expressed in a cardiac cell or when skeletal muscle receptors are expressed in a non-skeletal muscle cell.

The intriguing implication of this result is that some factor (or absence of some factor) associated with a skeletal muscle cell appears to reduce the average current through both the cardiac and the skeletal DHPR, either by lowering the conductance or the average open-time of the channels, the latter including the case where certain DHPRs often open as calcium channels and others never do so. Perhaps this factor involves the level of phosphorylation or the association of the DHPRs with the release channels. Nevertheless, this important observation still does not allow us to discriminate between hypotheses (2) and (3).

Department of Zoology,

G. D. LAMB

La Trobe University,

Bundoora, Melbourne 3083,

Australia

\footnotetext{
1. Schwartz, L. M. McCleskey, E.W.\&Almers, W. Nature 314 747-751 (1985).

2. Lamb, G. D. \& Walsh, T. J. Physiol., Lond. 393, 595-617 (1987).

3. Rios, E. \& Brum, G. Nature 325, 717-720 (1987).

4. Tanabe, T. et al. Nature 336, 134-139 (1988).

5. De Jongh, K. S., Merrick, D. K. \& Catterall, W. A. Proc, natn Acad. Sci. U.S.A. 86, 8585-8589 (1989).

6. Nunkio, K., Florio, V. \& Catterall, W. A. Proc. natn. Acad. Sci U.S.A. 86, 6816-6820 (1989)

7. Tanabe, T. et al. Nature 346, 567-569 (1990)

8. Adams, B. A.et al. Nature 346, 569-572 (1990).

9. Field, A. C., Hill C. \& Lamb, G. D. J. Physiol., Lond. 406 277-297 (1988).

10. Perez-Reyes, E. et al. Nature 340, 233-236 (1989).
} 